\title{
A case study on therapeutic management of a cross-bred downer cow
}

\author{
Subham Das', Biju P. Habeeb², C.G. Umesh², \\ S. Ajithkumar ${ }^{3}$ and N.S. Jinesh Kumar ${ }^{4}$ \\ Department of Veterinary Clinical Medicine, Ethics and Jurisprudence \\ College of Veterinary and Animal Sciences, \\ Pookode, Wayanad, Kerala-673576. India. \\ Kerala Veterinary and Animal Sciences University
}

Citation: Subham, D., Biju, P. H., Umesh C. G., , Ajithkumar S., and Jinesh Kumar N. S., 2021. A case study on therapeutic management of a cross-bred downer cow. J. Vet. Animal. Sci. 52(2): 208-210. DOI: https://doi.org/10.51966/jvas.2021.52.2.208-210

Received: 10.03.2021

Accepted: 12.04.2021

Published:01.06.2021

\begin{abstract}
A five year old cross bred cow, 24 hours post calving was presented to Teaching Veterinary Clinical Complex (TVCC), Pookode, with the history of recumbency 24 hours post calving. The serum biochemical parameters of calcium, phosphorus and potassium on the first day of presentation were $7.93 \mathrm{mg} / \mathrm{dL}, 3.82 \mathrm{mg} / \mathrm{dL}$ and $3.67 \mathrm{mEq} / \mathrm{L}$, respectively. Tentatively the condition was diagnosed as downer cow with metabolic origin. The cow was treated with calcium borogluconate, flunixine meglumine and inj. Vitamin $B_{1}, B_{6}, B_{12}$, sodium acid phosphate, vitamin $A D E$, Selenium, Biotin liquid for 7 days. Along with this, potassium chloride was administered for two days. The supportive treatment was done with lifting of cow using cow sling. Sand bedding was provided along with physiotherapy of rolling of the recumbent cow alternate ways six times a day. The serum biochemical parameters became normal on $8^{\text {th }}$ day and the cow recovered by $13^{\text {th }}$ day.
\end{abstract}

Key words: Downer cow, cow sling, Potassium Chloride

Downer cows are the cows which are recumbent for more than 24 hours (Constable et al., 2017). Delay in treatment and management results in pressure induced myositis and neuritis, and leads to poor prognosis. A case of successful recovery of a cross bred downer cow is reported. The cow was presented to TVCC, Pookode, 24 hours post calving with a history of sternal recumbency, crawling on forelimbs and inability to stand. The cow was able to hold its head up, exhibited wagging of tail with perineal response (Van Metre et al., 2001). No musculo-skeletal abnormalities were observed on physical examination. The cow was alert and clinical examination

1. MVSc Scholar and corresponding author: email: subhamd394@gmail.com Ph.8590129161

2. Assistant Professor

3. Professor and Head

4. Assistant Professor, Department of Veterinary Surgery and Radiology

Copyright: ( 2021 Subham Das et al. This is an open access article distributed under the terms of the Creative Commons Attribution 4.0 International License (http://creativecommons.org/licenses/by/4.0/), which permits unrestricted use, distribution, and reproduction in any medium, provided the original author and source are credited. 
revealed normal temperature $\left(100.9^{\circ} \mathrm{F}\right)$, respiration (24/minute), rumen motility $(2 / 5$ minutes), elevation of heart rate (86 beats / minute). Haematological parameters viz:- Total erythrocyte count (TEC) $8.77 \times 10^{6} / \mu \mathrm{L}$, total leukocyte count (TLC) $9.3 \times 10^{3} / \mu \mathrm{L}$, different leukocyte count (DLC) viz:- granulocyte 24 per cent, monocyte six per cent and lymphocyte 70 per cent, haemoglobin $(\mathrm{Hb}) 10.89 \mathrm{~g} / \mathrm{dL}$ and packed cell volume (PCV) 26.3 per cent respectively. Serum biochemical parameters viz :-calcium (7.93 mg/dL), phosphorus (3.82 $\mathrm{mg} / \mathrm{dL}$ ) and potassium ( $3.67 \mathrm{mEq} / \mathrm{L}$ ) were below the normal. Muscle weakness might have been due to reduced calcium which resulted in recumbency leading to downer cow syndrome. Hypophosphatemia may be due to increased activity of parathyroid hormone and loss of phosphorus through milk. Hypokalemia might be attributed to reduction in the resting potential of cell membrane which resulted in decreased excitability of neuromuscular tissue and muscle weakness (Radostits et al., 2007).

The cow was treated with $225 \mathrm{ml}$ of 25 per cent calcium borogluconate as slow IV, once daily for two days (Constable et al., 2017), potassium chloride @ $120 \mathrm{gm}$ twice daily orally for three days (Constable et al., 2013 ; Beder et al., 2020), flunixin meglumine @ $1.1 \mathrm{mg} / \mathrm{kg}$ body weight once daily IV, for three days (Jesse et al., 2016) and Inj. vitamin $B_{1}, B_{6}$ and $B_{12}-15$ $\mathrm{ml}$ daily IV, sodium acid phosphate @ 60g, orally once daily and supportive treatment by vitamin ADE, Selenium, Biotin liquid @ $10 \mathrm{ml}$ orally, once daily for seven days. Soft bedding was provided with sand and the animal was lifted using cow sling once daily. The recumbent cow was rotated alternatively six times a day, the skin wounds due to recumbency were cleaned daily and herbal wound healing ointment was applied locally. Green grass, dairy cattle feed, drinking water were provided as per requirement of the animal. Physiotherapy was given with body massage to improve the blood circulation and neurological reflexes (Huxley et al., 2010). During the course of treatment, the cow was milked twice daily. The animal recovered eventfully on $13^{\text {th }}$ day, similar observation was reported by Poulton et al., 2016.

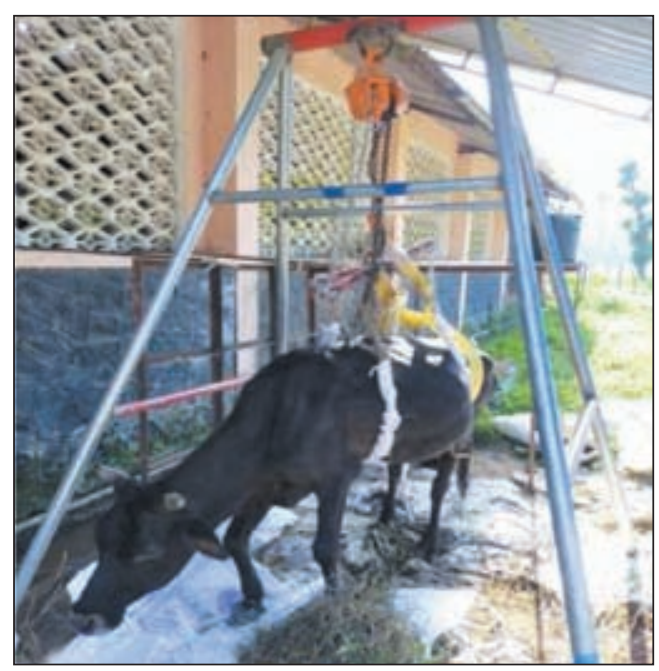

Fig: 1 Downer cow on sling

\section{Summary}

In this study, the post-parturient downer cow with reduced serum calcium, phosphorus, potassium was treated with calcium borogluconate, flunixine meglumine @ $1.1 \mathrm{mg} / \mathrm{kg}$ body weight $\mathrm{i} / \mathrm{v}$ for three days, Inj.Vitamin $B_{1}, B_{6}, B_{12}$, sodium acid phosphate and vitamin $A D E$, Selenium, Biotin liquid for 7 days and potassium chloride for two days along with the routine physiotherapy, lifting the cow and massaging which made the animal to stand on its feet on $8^{\text {th }}$ day. The serum calcium, phosphorus and potassium increased to be back to normal level and the cow recovered on $13^{\text {th }}$ day.

It was concluded that while attending a recumbent cow without delay, with accurate diagnosis and appropriate treatment along with the supportive care such as physiotherapy, providing soft bedding with sand, changing recumbency posture by turning and lifting the animal daily using body sling with support to stand would result in complete recovery.

\section{Acknowledgement}

The authors are thankful to the Dean, COVAS, Pookode, Head, Teaching Veterinary Clinical Complex and Professor and Head, Department of Veterinary Clinical Medicine, Ethics and Jurisprudence for providing facilities. 


\section{References}

Beder, N.A., El-Kasrawy, N.I., Goda, W.M. and Abdel-Latif, M.A. 2020. Prognostic value of serum potassium level predicting the duration of recumbency in downer cows due to metabolic disorders. Trop. Anim. Hlth. Prod. 2020:1-6.

Constable, P., Grünberg, W., Staufenbiel, R. and Stämpfli, H.R. 2013. Clinicopathologic variables associated with hypokalemia in lactating dairy cows with abomasal displacement or volvulus. J. Am. Vet. Med. Assoc. 242(6): 826-835.

Constable, P. D., Hinchcliff, K. W, Done, S. H. and Grunberg, W. 2017. Veterinary Medicine - A text book of the diseases of cattle, horses, sheep, pigs, and goats. (11 ${ }^{\text {th }}$ Ed.). Elsevier, St. Louis, Missouri. pp. 1693-1699.

Huxley, J.N., Archer, S.C., Biggs, A.M., Bradley, A.J., Breen, J.E., Green, M.J., Higgins, H.M., Hudson, C.D., Husband, J.A., May, W. and Reader, J.D. 2010. An expert review of the diagnosis, prognosis and treatment of recumbency in adult cattle. Cattle Practice. 18(1): 53-60.

Jesse, F.F.A., Chung, .E.L.T., Abba, Y., Sadiq, M.A., Adamu, L., Hambali, I.U., Bitrus, A.A., Zabri, N.S., Lila, M.A.M., Haron, A.W. and Saharee, A.A. 2016. Therapeutic management of stage II milk fever with retained placenta in a cow. Int. J. Livest. Res. 6(9): 83-87.

Poulton, P.J., Vizard, A.L., Anderson, G.A. and Pyman, M.F. 2016. High-quality care improves outcome in recumbent dairy cattle. Aust. Vet. J. 94(6): 173-180.

Radostitis, O.M., Gay, C.C., Hinchcliff, K.W. and Constable, P.D. 2007. Veterinary Medicine- $A$ text book of the diseases of cattle, horses, sheep, pigs and goats. (10 ${ }^{\text {th }}$ Ed.). Elsevier. W.B. Saunders Company, Philadelphia. pp. 2045-2050.

Van Metre, D.C., Callan, R.J. and Garry, F.B. 2001. Examination of musculoskeletal system in recumbent cattle. Food Anim. Comp. 23(2): S5-S13. 